\title{
Modified CVD of Nanoscale Structures in and EVD of Thin Layers on Porous Ceramic Membranes
}

\author{
L. G. J. de Haart, Y. S. Lin, K. J. de Vries \& A. J. Burggraaf \\ Laboratory of Inorganic Chemistry, Materials Science and Catalysis, Faculty of Chemical Technology, \\ University of Twente, P.O. Box 217, 7500 AE Enschede, The Netherlands
}

(Received 28 September 1990; revised version received 26 February 1991; accepted 11 March 1991)

\begin{abstract}
Experiments on the modified chemical vapour deposition (CVD) and the electrochemical vapour deposition (EVD) of yttria-stabilized zirconia on porous substrates are reported. It is shown that, in the CVD stage, deposition occurs in a small $(<20 \mu \mathrm{m})$ region at the edge of the substrate, very likely leading to pore narrowing. This result illustrates the feasibility of the CVD technique for the modification of ceramic membranes to the (sub) nanometer scale. Film growth in the EVD stage is shown to be controlled by the inpore diffusion of the oxygen source reactant for short $(<5 h)$ deposition times. The yttria to zirconia ratio in the deposited film is determined by the ratio present in the vapour phase. Very thin $(\leq 2 \mu \mathrm{m})$ films can be deposited, which have a potential application in solid oxide fuel cells.
\end{abstract}

Auf porösen Substraten wurden mittels einer modifizierten chemischen (CVD) und einer elektrochemischen (EVD) Abscheidung aus der Dampfphase Yttrium stabilisiertes Zirkonoxid erzeugt. Es zeigt sich, daß bei der CVD-Technik die Schichtbildung in einem kleinen Bereich $(<20 \mu \mathrm{m})$ an der Oberfläche des Substrats stattfindet, was höchstwahrscheinlich zu einer Verengung der Poren führt. Dieses Ergebnis zeigt den möglichen Einsatz der CVD-Technik zur Modifizierung keramischer Membranen im (sub)nanometer Bereich. Im Fall der EVD zeigt sich, daß das Schichtwachstum bei kurzen Versuchszeiten $(<5 h)$ durch das Diffusionsverhalten der Sauerstoff liefernden Verbindung in die Poren kontrolliert wird. Das $\mathrm{Y}_{2} \mathrm{O}_{3} / \mathrm{ZrO}_{2}$-Verhältnis in den Schichten wird durch das entsprechende Verhältnis in der Gasphase eingestellt. Es können sehr dünne Schichten $(\leq 2 \mu \mathrm{m})$ abgeschieden werden, die möglicherweise für die Brennstoffzelle von Bedeutung sein können.

On rapporte ici les résultats d'expériences concernant le dépôt chimique en phase vapeur modifié (CVD) et le dépôt électrochimique en phase vapeur (EVD) de la zircone stabilisée par l'yttrine sur des substrats poreux. On montre que lors de l'étape CVD, la déposition se produit dans un domaine de faible étendue $(<20 \mu \mathrm{m})$, au bord du substrat, conduisant avec une forte probabilité à un rétrécissement des pores. Ce résultat met en évidence la capacité de la technique CVD quant à la modification de membranes céramiques jusqu'à l'échelle (sub)nanométrique. Lors de l'étape EVD, la croissance du film est contrôlée par la diffusion dans les pores de la source d'oxygène lors de temps de déposition courts $(<5 h)$. Le taux yttrine/zircone dans le film déposé est déterminé par le taux en présence dans la phase vapeur. Des films très minces $(\leq 2 \mu \mathrm{m})$ peuvent être déposés, possèdant un potentiel d'application pour les cellules de combustible solide à base d'oxyde.

\section{Introduction}

The electrochemical vapour deposition (EVD) process was developed by Westinghouse Electric Corporation (Pittsburg, PA, USA) out of the necessity of fabricating gas-tight metal oxide layers for high-temperature solid oxide fuel cells (SOFC) on porous substrates. ${ }^{1}$ The yttria-stabilized zirconia (YSZ) electrolyte layer in an SOFC has to be thin in order to minimize the ohmic polarization losses. To achieve mechanical stability the layer has to be supported, but a support porosity is required to allow 
for gas diffusion to the YSZ layer during operation of the SOFC. For use in high-temperature electrolysis cells (HTEC), the YSZ electrolyte layer has to fulfil the same requirements. In the production of these HTEC, Dornier Systems $\mathrm{GmbH}^{2}$ (Friedrichshafen, FRG) therefore made use of a similar EVD process for YSZ electrolyte layer fabrication. More recently Carolan \& Michaels ${ }^{3}$ reported on growth rates and mechanism ${ }^{4}$ and morphology ${ }^{5}$ of electrochemical vapour deposited yttria-stabilized zirconia (EVD YSZ) films.

The principles of EVD have been outlined in detail in the literature. ${ }^{1-3,6} \mathrm{~A}$ porous substrate separates a mixture of (several) metal chlorides and an oxygen source reactant (water and/or oxygen). Initially the reactants inter-diffuse in the substrate pores and react to form a metal oxide, which is deposited on the pore wall. Continued deposition causes pore narrowing until eventually the pores become plugged with the metal oxide. These steps can all be considered as modified chemical vapour deposition (CVD). The actual film growth in the subsequent EVD stage relies on the mixed conductivity of the deposited metal oxide. Oxygen or water is reduced at the oxygen/film interface and oxygen ions migrate through the growing film to the metal chloride/film interface, counterbalanced by electron migration in the film. The oxygen ions react at the metal chloride/film interface with the metal chlorides to form again the metal oxide.

Up to now attention has been paid only to the two-step CVD + EVD process for the fabrication of thin films on porous substrates, apart from the more phenomenological study of the CVD stage by Carolan \& Michaels. ${ }^{3}$ The CVD stage itself is, however, also of particular interest for the modification of ceramic membranes. ${ }^{6}$ With their thermal, structural and chemical stability, ceramic membranes find increasing application in processes for liquid and gas separation and catalytic reactions. ${ }^{7,8}$ The synthesis of ceramic membranes with proper surface chemistry and desired pore size is essential for membrane applications. With the so-called sol-gel technique, ceramic membranes with nanoscale pore size can be synthesized. ${ }^{9,10}$ With the available methods it is, however, difficult to prepare ceramic membranes with pore sizes on the subnanometer scale without the use of silica. ${ }^{10}$ The modified CVD process offers the possibility of modifying ceramic membranes, not only by decreasing the pore size to the subnanometer scale, but also by coating the internal pore surface and thus modifying the membrane chemically. Furthermore, the integration of a ceramic membrane with a coarse

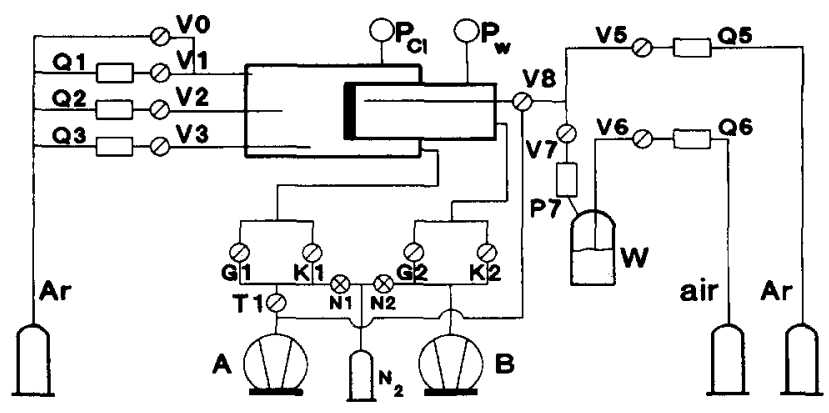

Fig. 1. Schematic diagram of the CVD/EVD apparatus. $A$ and $B$, vacuum pumps; W. water sparger; $G 1, G 2$ and $T 1$, large automatic valves; $\mathrm{K} 1$ and $\mathrm{K} 2$, small automatic valves; V0-3, V5-8, valves; Q1-3, Q5 and Q6, mass flow controllers; P7, pressure controller; $\mathrm{N} 1$ and $\mathrm{N} 2$, automatic needle valves; $\mathrm{P}_{\mathrm{Cl}}$ and $\mathbf{P}_{\mathrm{W}}$, pressure gauges.

porous substrate will make it possible to deposit much thinner $(\leq 2 \mu \mathrm{m})$ layers using the two-step CVD + EVD process. These very thin films have, besides a promising use in SOFC, ${ }^{11}$ a potential application in membrane separation processes too, because of their high selectivity in oxygen permeation.

In view of both applications, namely ceramic membrane modification using CVD and thin layer formation using EVD, investigations have been performed on the CVD and EVD of yttria-stabilized zirconia on porous alumina substrates. It is the purpose of this paper to report on the experimental procedures and results obtained in this study. The results will be discussed using the mathematical models developed for both the $\mathrm{CVD}^{12}$ and the EVD $^{13}$ stages.

\section{Experimental}

\subsection{The CVD/EVD apparatus}

Figure 1 shows a schematic diagram of the in-house purpose-built CVD/EVD apparatus, consisting of three sections: the reactor, the vacuum control section and the reactant delivery section. The reactor, which is shown in a detailed schematic view in Fig. 2, consists of three dense alumina tubes. The biggest one is $2 \mathrm{~m}$ long and has an inside diameter of $75 \mathrm{~mm}$. The two other tubes are mounted concentrically inside this largest tube, one on each side (see

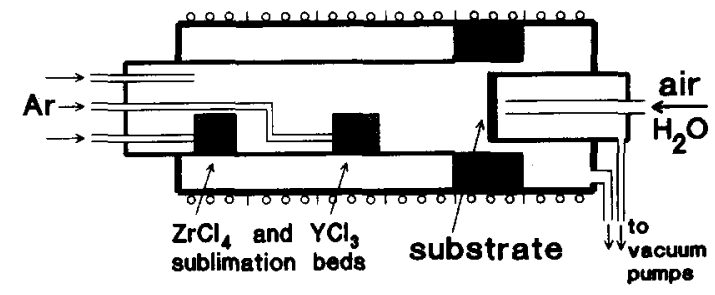

Fig. 2. Detailed schematic view of the central part of the CVD/EVD reactor system. 
Fig. 2). The porous substrate is cemented into the end of the smallest tube (referred to as the supporting tube), thus separating the reactor space into two chambers, referred to as chloride chamber (volume $=8030 \mathrm{ml}$ ) and water chamber (volume $=$ $375 \mathrm{ml}$ ), respectively. In the bigger inner alumina tube the sublimation beds for the metal chlorides are placed. Two types of sublimation beds were used. The first one was constructed of graphite and an Ar gas stream was passed over the chloride powder in the bed. The second type was made of quartz and in this one the Ar gas stream was passed through a packed bed of the chloride powder mixed with graphite granules. The tube with the sublimation beds inside is supported at the end by a graphite ring, which acts simultaneously as an oxygen getter in the chloride chamber and as the provider of an isothermal zone for the substrate (see Fig. 2). The reactor is placed in a six-zone tubular furnace (Vectstar), each zone being controlled by a Eurotherm 820 temperature controller to give the desired temperature profile in the reactor.

Two vacuum pumps (Leybold BCS-D65; A and B in Fig. 1) are used to regulate the pressures in the chloride and water chambers of the reactor, respectively. Two pressure sensors (MKS Baratron; $\mathrm{P}_{\mathrm{Cl}}$ and $\mathrm{P}_{\mathrm{w}}$ in Fig. 1) are used to monitor the pressures in the two chambers.

A set of three mass flow controllers (Brooks 5850TR; Q1, Q2 and Q3 in Fig. 1) is used to regulate the Ar carrier gas streams to the chloride chamber and the metal chloride sublimation beds, respectively.

The hydrogen/water or air/water mixture was generated by bubbling hydrogen or air through a heated sparger (W in Fig. 1) filled with doublydistilled water. The water sparger was placed in a

Table 1. Specifications of the chemicals and substrates used in the CVD/EVD experiments

\begin{tabular}{|c|c|c|c|c|c|}
\hline \multirow{4}{*}{$\begin{array}{l}\text { Reactants } \\
\qquad \begin{array}{l}\mathrm{ZrCl}_{4}{ }^{a} \\
\mathrm{YCl}_{3}{ }^{a} \\
\mathrm{H}_{2} \mathrm{O}\end{array}\end{array}$} & \multicolumn{5}{|c|}{ Carrier gases } \\
\hline & \multirow{3}{*}{\multicolumn{2}{|c|}{$\begin{array}{l}99 \cdot 9 \%(200 \mathrm{mesh}) \\
99 \cdot 9 \%(60 \mathrm{mesh}) \\
\text { doubly-distilled }\end{array}$}} & $\mathrm{Ar}^{b}$ & \multirow{3}{*}{\multicolumn{2}{|c|}{$\begin{array}{l}99.999 \% \text { (UHP 5.0) } \\
99.999 \% \text { (UHP 5.0) } \\
\text { Technical grade }\end{array}$}} \\
\hline & & & $\mathrm{H}_{2}^{b}$ & & \\
\hline & & & $\operatorname{Air}^{c}$ & & \\
\hline \multicolumn{2}{|c|}{ Substrate discs } & \multicolumn{2}{|l|}{$\begin{array}{c}\text { Type A } \\
(\alpha-\text { alumina })\end{array}$} & \multicolumn{2}{|c|}{$\begin{array}{c}\text { Type B } \\
\left(x \text {-alumina/La }(\mathrm{Sr}) \mathrm{MnO}_{3}\right. \\
\left.\text { two-layer system }{ }^{d}\right)\end{array}$} \\
\hline \multicolumn{2}{|c|}{ Diameter $(\mathrm{mm})$} & 12 & & \multicolumn{2}{|c|}{12} \\
\hline \multicolumn{2}{|c|}{ Thickness (mm) } & 2 & & 1 & 0.035 \\
\hline \multicolumn{2}{|c|}{ Porosity (\%) } & 50 & & 50 & 70 \\
\hline \multirow{2}{*}{\multicolumn{2}{|c|}{$\begin{array}{l}\text { Mean pore } \\
\text { diameter }(\mu \mathrm{m})\end{array}$}} & & & & \\
\hline & & $0 \cdot 2$ & & 10 & 0.4 \\
\hline
\end{tabular}

${ }^{a}$ CERAC/pure.

${ }^{n}$ UCAR.

"Hoekloos.

"Supplied by ECN, Petten, The Netherlands. thermostat bath (Tamson T2500) to ensure constant temperature. The hydrogen or air mass flow rate and total pressure of the water-saturated mixture in the sparger were controlled by a mass flow controller (Brooks 5850-TR; Q6 in Fig. 1) and a pressure controller (Brooks 5866; P7 in Fig. 1), respectively. The water-containing gas mixture could be directed either to the back of the substrate in the water chamber or directly to the pump by switching a three-way valve (V8 in Fig. 1). On the water side was placed an extra Ar gas line (Q5 in Fig. 1), to flush the water chamber in the reactor with Ar.

All components of the total system were chosen and the system constructed so that the CVD/EVD process was automatically controlled by a personal computer (G2 Systems AT), preserving, however, the possibility for manual control.

\subsection{Materials}

In Table 1 the chemicals used in the CVD/EVD experiments are specified. Carrier gas for the water was either $\mathrm{H}_{2}$ or air. Two types of substrates (discs; $12 \mathrm{~mm}$ in diameter) were used, referred to as type A and $\mathrm{B}$, respectively, and specified also in Table 1 . The $\alpha$-alumina (type A) substrate is normally used as support for the $\gamma$-alumina ceramic membrane top layers. In these CVD/EVD experiments it serves as a model substrate. The two-layer (type B) substrate was manufactured by ECN (Petten, The Netherlands). ${ }^{14}$ It consists of a thin porous $\mathrm{Sr}_{0.15} \mathrm{La}_{0.85} \mathrm{MnO}_{3}$ (15SLM) perovskite layer on a coarse porous $\alpha$-alumina substrate. The $15 \mathrm{SLM}$ layer serves as cathode in an SOFC after deposition of the YSZ electrolyte layer. ${ }^{11}$ The substrates were mounted into the end of the alumina supporting tube using a ceramic cement (Aremco 503).

The zirconium and yttrium chlorides are both very hygroscopic. In order to prevent the formation of hydrates and/or oxychlorides they were handled in a glove box flushed with dry nitrogen. The glove box was directly attached to the chloride side of the reactor. The metal chloride sublimation beds could therefore be transferred directly from the glove box into the reactor. The quartz sublimation beds were filled with a mixture of the metal chloride and graphite granules. The graphite acts as oxygen getter for the residual oxygen still present in the gas atmosphere in the glove box and chloride chamber.

\subsection{CVD/EVD experimental conditions and procedures}

The standard experimental conditions for the CVD/EVD experiments are given in Table 2. After the supporting tube with the porous substrate and 
Table 2. Standard CVD/EVD experimental conditions

\begin{tabular}{ll}
\hline Substrate temperature & $1000^{\circ} \mathrm{C}$ \\
Reactor pressure & $2 \mathrm{mbar}(200 \mathrm{~Pa})$ \\
$\begin{array}{l}\mathrm{ZrCl}_{4} \text { sublimation bed } \\
\quad \text { temperature }\end{array}$ & $155^{\circ} \mathrm{C}$ \\
$\mathrm{YCl}_{3}$ sublimation bed & \\
$\quad$ temperature & $613^{\circ} \mathrm{C}$ \\
$\mathrm{YCl}_{3} / \mathrm{ZrCl}{ }_{4}$ ratio in vapour & $\sim 3 / 10$ \\
$\begin{array}{l}\text { Total } \mathrm{Ar} \text { carrier gas stream on } \\
\text { chloride side }\end{array}$ & $27.5 \mathrm{ml}(\mathrm{STP}) \mathrm{min}^{-1}$ \\
$\mathrm{H}_{2}$ or air carrier gas stream on & \\
$\quad$ water side & $3.5 \mathrm{ml}(\mathrm{STP}) \mathrm{min}^{-1}$ \\
Water sparger temperature & $40^{\circ} \mathrm{C}$ \\
Total pressure in water sparger & $150 \mathrm{mbar}(15 \mathrm{kPa})$ \\
$\mathrm{H}_{2} / \mathrm{H}_{2} \mathrm{O}$ or air $/ \mathrm{H}_{2} \mathrm{O}$ ratio & \\
in vapor & $\sim 1 / 1$ \\
\hline
\end{tabular}

the metal chloride sublimation beds had been placed in the reactor, the reactor was first evacuated and heated to the desired temperature. A restrictor was placed in the pump line from the chloride chamber (near K1; see Fig. 1) to reduce the initial evacuation rate in order to prevent blowing out of the chloride powders from the sublimation beds. This initial stage of evacuation (from atmospheric pressure to around $20 \mathrm{mbar}$ took about $15 \mathrm{~min}$. The final pressure of usually 2 mbar ( $200 \mathrm{~Pa}$ ) was then reached within a minute by opening the large valve G1 (see Fig. 1). The heating of the furnace (usually to $1000^{\circ} \mathrm{C}$ for the substrate zone) took about $5 \mathrm{~h}$. During heating both chambers were flushed with Ar via the mass flow controllers (MFC) Q1 and Q5 (see Fig. 1). At the time when the temperature profile and the total pressure were stabilized, $\mathrm{Ar}$ carrier gas streams were also directed to the $\mathrm{ZrCl}_{4}$ and $\mathrm{YCl}_{3}$ sublimation beds by setting the MFCs Q2 and Q3, respectively. Simultaneously the Ar flush stream on the water side was stopped and the three-way valve V8 was switched directly to the pump A (see Fig. 1). The MFC Q6 and pressure controller P7 were set to generate the desired $\mathrm{H}_{2} / \mathrm{H}_{2} \mathrm{O}$ or air $/ \mathrm{H}_{2} \mathrm{O}$ mixture, which was for at least 5 min bypassed directly to the pump. The actual deposition was started by switching V8 to direct the water-containing gas stream to the back of the substrate in the water chamber. The deposition process was stopped after the desired deposition time by switching V8 again back directly to the pump. In all CVD/EVD experiments, the total pressures in the water chamber and in the chloride chamber were kept the same, i.e. there was no absolute pressure difference between the two chambers.

\subsection{In-situ Ar gas permeation measurements}

In order to monitor the extent of the deposition during the initial CVD stage, in-situ Ar gas permeation measurements were performed at certain time intervals. After the deposition process was stopped, the reactant supply to both sides was shut off completely and the lines of both chambers to the pumps were closed. The chloride chamber was then slowly filled with Ar (via Q1) to a pressure of 200 mbar and the water chamber was filled with $\mathrm{Ar}$ (via Q5) to a pressure of 100 mbar. With this initial pressure difference of $100 \mathrm{mbar}$ over the substrate (at an average pressure of $150 \mathrm{mbar}$ ) the pressure rise in the water chamber was measured as a function of time, from which the Ar permeability of the substrate was calculated. In most cases the permeation measurements were performed at the above given condition of an average pressure of $150 \mathrm{mbar}$. In several cases the same measurements were also performed at average pressures of $450 \mathrm{mbar}$ (chloride chamber, $500 \mathrm{mbar}$; water chamber, $400 \mathrm{mbar}$ ) and $750 \mathrm{mbar}$ (chloride chamber, 800 mbar; water chamber, 700 mbar). All in-situ Ar gas permeation measurements were performed at the deposition temperature (usually $1000^{\circ} \mathrm{C}$ ).

\subsection{YSZ deposit characterization}

The phase structure, morphology, composition, composition profile and film thickness of the CVD deposits and EVD films were examined by XRD (Philips PW 1710; Ni-filtered Cu-K $\alpha$ ), SEM (JEOL JSM-35CF) and EDS (KEVEX). In all analyses, the EVD films were retained on the substrates.

\section{Results}

Table 3 summarizes the results of several CVD/EVD experiments on the deposition of yttriastabilized zirconia (YSZ) on porous substrates. All runs listed were performed under the standard experimental conditions (see Table 2). The additional experimental conditions, such as substrate type, oxygen source reactant and total deposition time, are for each case given in Table 3.

\subsection{In-situ Ar gas permeation measurements}

Figure 3 shows the results of the in-situ measured $\mathrm{Ar}$ gas permeation performed during the CVD run number 89-34 (case 3 in Table 3). After each 5 min of deposition the CVD process was halted and a measurement was carried out. The initial Ar gas permeability was $4.03 \times 10^{-6} \mathrm{~mol} \mathrm{~s}^{-1} \mathrm{~Pa}^{-1} \mathrm{~m}^{-2}$ (at $1000^{\circ} \mathrm{C}$ ). This value is consistent with the permeability of a similar type A substrate measured at room temperature using a special permeation measuring cell. Continued deposition resulted in a gradually 


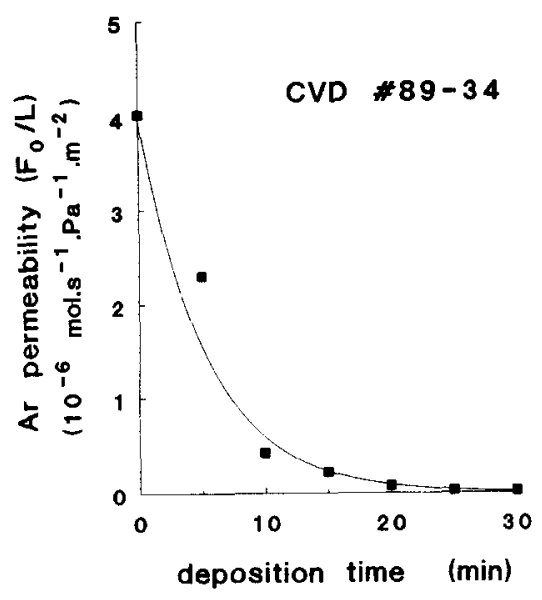

Fig. 3. In-situ measured Ar gas permeability of the CVD sample number 89-34 as function of the CVD deposition time.

Measured at $1000^{\circ} \mathrm{C}$ and an average pressure of $15 \mathrm{kPa}$.

decreasing permeability, indicating YSZ deposition in the pores of the substrate. The lower limit of detection permeability was around $0.02 \times 10^{-6} \mathrm{~mol}$ $\mathrm{s}^{-1} \mathrm{~Pa}^{-1} \mathrm{~m}^{-2}$. This value was reached after a total of $30 \mathrm{~min}$ deposition. This was considered to be the time of pore closure. Similar in-situ gas permeation measurements to determine pore closure were used by Carolan \& Michaels. ${ }^{3}$ The value of the gas permeability at which these authors considered the substrate to be plugged was however 300 times larger than in the present case, and was of the order of magnitude of the initially (i.e. before deposition) measured permeability for the present substrates. The accuracy of the pore closure time determination also depends on the time intervals used between the subsequent permeation measurements. In normal practice, the time intervals were 15 or $30 \mathrm{~min}$. The example given here with much shorter intervals of $5 \mathrm{~min}$ is merely to illustrate the in-situ method of monitoring the CVD stage. It is not yet clear if the deposition is in any way affected by this temporary stopping of the process.

All other runs performed under the same experi- mental conditions as in case 3 (see Table 3 ) showed a similar dependence of the Ar gas permeability on the deposition time. The pore closure time was $30-35 \mathrm{~min}$. A slightly larger pore closure time was observed in the first series of experiments, when a $\mathrm{H}_{2} / \mathrm{H}_{2} \mathrm{O}$ mixture was used as oxygen source reactant (case 1 in Table 3). The increase in pore closure time, however, cannot be attributed completely to this different oxygen source reactant, because in this first series of experiments the chloride sublimation beds were made out of graphite (see Section 2.1), which probably resulted in a slightly lower chloride vapour concentration. The same arguments hold for the slightly increased pore closure time observed in case 2 (see Table 3). A more pronounced increase in pore closure time was observed with dry air as oxygen source reactant. In this case it took more than $2 \mathrm{~h}$ deposition time before the substrate became plugged. The effects of the different experimental parameters on the CVD results are reported in more detail elsewhere. ${ }^{15}$

For the two-layer type B substrates, the initial Ar gas permeability was normally around $20 \times$ $10^{-6} \mathrm{~mol} \mathrm{~s}^{-1} \mathrm{~Pa}^{-1} \mathrm{~m}^{-2}$ (at $1000^{\circ} \mathrm{C}$ ), which is about 5 times larger than for the type A substrates under the same conditions, although for the sample number 90-23 (case 5 in Table 3) a lower value of $5.8 \times 10^{-6} \mathrm{~mol} \mathrm{~s}^{-1} \mathrm{~Pa}^{-1} \mathrm{~m}^{-2}$ was measured. Gas permeation measurements performed at room temperature using the special permeation measurement cell showed the permeability of the type B substrate to be around 40 times larger than the permeability of the type A substrate, which is in line with the much larger mean pore size and the very thin top layer of this type B substrate (see Table 1). The reason for the much smaller difference observed between the initial Ar gas permeabilities of the type $B$ and the type A substrates at $1000^{\circ} \mathrm{C}$ is not yet clear. Sintering of the $15 \mathrm{SLM}$ perovskite top layer of the type B substrate during heating is unlikely,

Table 3. Summary of experimental CVD/EVD results

\begin{tabular}{|c|c|c|c|c|c|}
\hline & Case 1 & Case 2 & Case 3 & Case 4 & Case 5 \\
\hline Run number & $89-13$ & $89-23$ & 89-34 & 90-02 & $90-23$ \\
\hline Substrate & $\begin{array}{l}\alpha \text {-Alumina } \\
\text { (type A) }\end{array}$ & $\begin{array}{l}\alpha \text {-Alumina } \\
\text { (type A) }\end{array}$ & $\begin{array}{c}\alpha \text {-Alumina } \\
\text { (type A) }\end{array}$ & $\begin{array}{c}\alpha \text {-Alumina } \\
\text { (type A) }\end{array}$ & $\begin{array}{c}\text { Two-layer system } \\
\text { (type B) }\end{array}$ \\
\hline Oxygen source & $\mathrm{H}_{2} \mathrm{O} / \mathrm{H}_{2}$ & Air (humid) & $\mathrm{H}_{2} \mathrm{O} / \mathrm{air}$ & $\mathrm{H}_{2} \mathrm{O} /$ air & $\mathrm{H}_{2} \mathrm{O} /$ air \\
\hline $\begin{array}{l}\text { Total deposition time } \\
\text { (h) }\end{array}$ & 4 & 4 & 1.5 & 1.6 & 1 \\
\hline $\begin{array}{l}\text { Pore closure time } \\
\text { (h) }\end{array}$ & 0.75 & $0 \cdot 75$ & $0 \cdot 5$ & $0 \cdot 6$ & $0 \cdot 5$ \\
\hline $\begin{array}{l}\text { EVD film thickness } \\
(\mu \mathrm{m})\end{array}$ & 4 & 5 & 1.5 & $1 \cdot 5$ & 8 \\
\hline $\begin{array}{l}\text { Film growth rate } \\
\qquad\left(\mu \mathrm{m} \mathrm{h}^{-1}\right)\end{array}$ & $1 \cdot 2$ & $1 \cdot 5$ & $1 \cdot 5$ & $1 \cdot 5$ & 16 \\
\hline
\end{tabular}


because during manufacturing the two-layer system had already been heat-treated at $1100^{\circ} \mathrm{C} .{ }^{14}$ The pore closure time observed for the type B substrate (case 5 in Table 3 ) was around $30 \mathrm{~min}$, which is comparable to that of the type A substrates.

The decrease of the Ar gas permeability definitely shows the deposition of YSZ in the substrate pores. Since, however, the permeability of a porous system is related to the product of the porosity and the mean pore radius, it is not yet clear which one actually decreases or whether both decrease. Therefore Ar gas permeation measurements were performed as a function of the average total pressure. The measurements were performed both in situ at $1000^{\circ} \mathrm{C}$ in the CVD/EVD reactor and at room temperature in the special permeation measuring cell on several samples before any deposition had taken place and after $15 \mathrm{~min}$ of deposition. In all cases an overall decrease of the permeability is observed, which will be discussed in Section 4.1.

\subsection{SEM/EDS analysis}

Figure 4 shows an SEM photograph of a crosssection of the CVD/EVD sample number 90-02 (case 4 in Table 3) near the edge that was exposed to the metal chloride vapour during deposition. In the secondary electron image (SEI: Fig. 4(b)) a very thin layer $(1-2 \mu \mathrm{m})$ can be observed on the porous $\alpha$ alumina substrate. The back-scattered electron image (BEI: Fig. 4(a)) shows that this layer is composed of $\mathrm{Zr}$ and $\mathrm{Y}$. The BEI shows additionally a $\mathrm{Zr}+\mathrm{Y}$ deposit in the pores of the $\alpha$-alumina substrate. The deposit penetrates to over $15 \mu$ m deep into the pores.

Figure 5 shows an SEM photograph of a crosssection of the CVD/EVD sample number 90-23 (case 5 in Table 3). The 15SLM perovskite layer was exposed to the metal chloride vapour during deposition. On top of the $35 \mu$ m thick 15SLM layer a YSZ layer with a thickness of around $8 \mu \mathrm{m}$ has been deposited in a total of $60 \mathrm{~min}$. Figure 6 shows the results of an EDS analysis of the cross-section shown in Fig. 5. The elemental mappings on $\mathrm{Y}, \mathrm{Zr}$ and $\mathrm{La}$, respectively, show again clearly the EVD YSZ layer on top of the two-layer $\mathrm{Al}_{2} \mathrm{O}_{3} / 15 \mathrm{SLM}$ substrate. The mappings on $\mathrm{Zr}$ and $\mathrm{Y}$ (Fig. 6) again show the deep penetration of the YSZ deposit into the pores of the substrate. The YSZ deposit

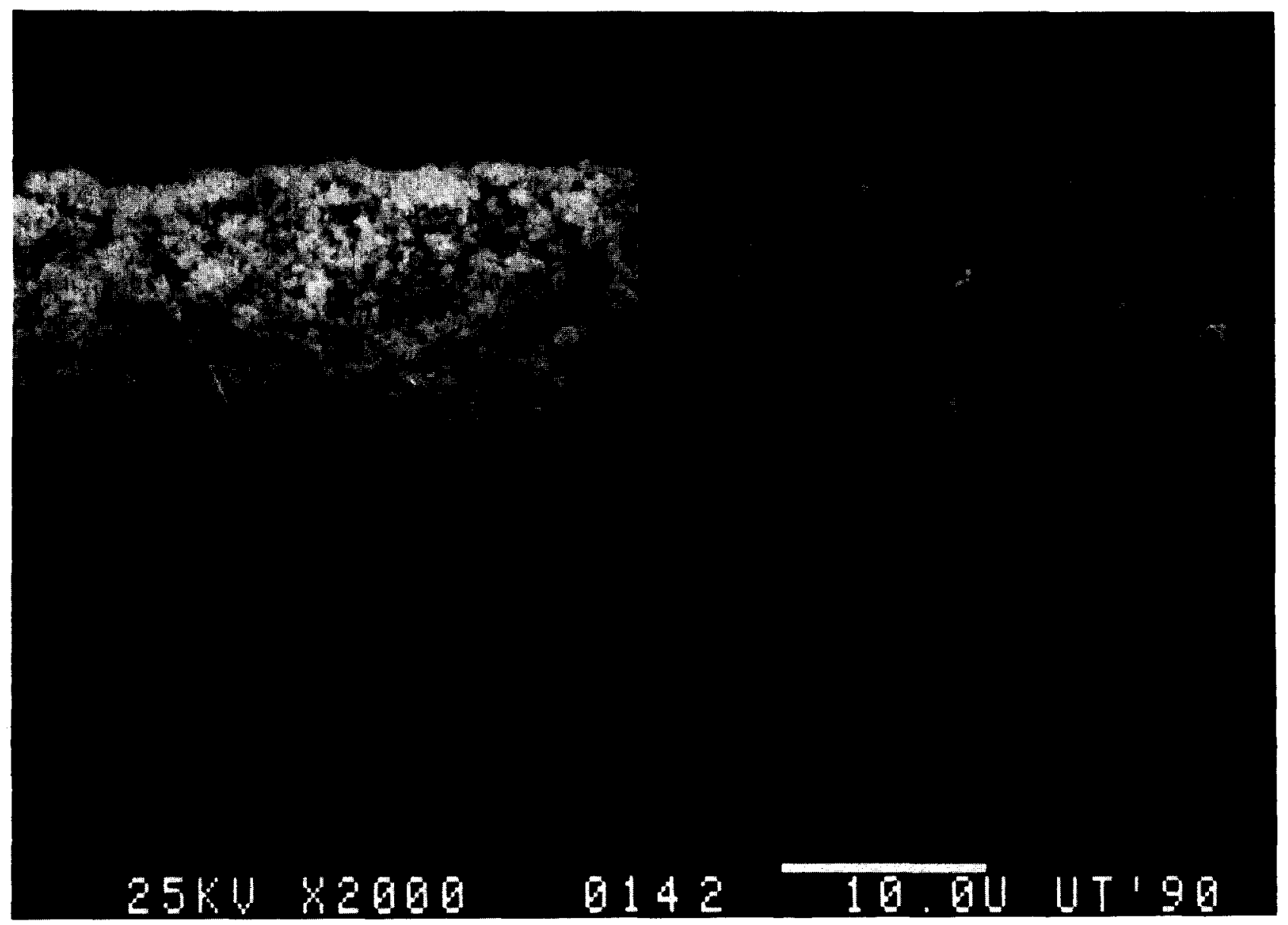

(a)

(b)

Fig. 4. SEM photograph of a cross-section of the CVD sample number 90-02. (a) Back-scattered electron image (BEI: composition; dark $=\mathrm{Al}$; light $=\mathrm{Zr}, \mathrm{Y}$ ); (b) secondary electron image (SEI: morphology). 


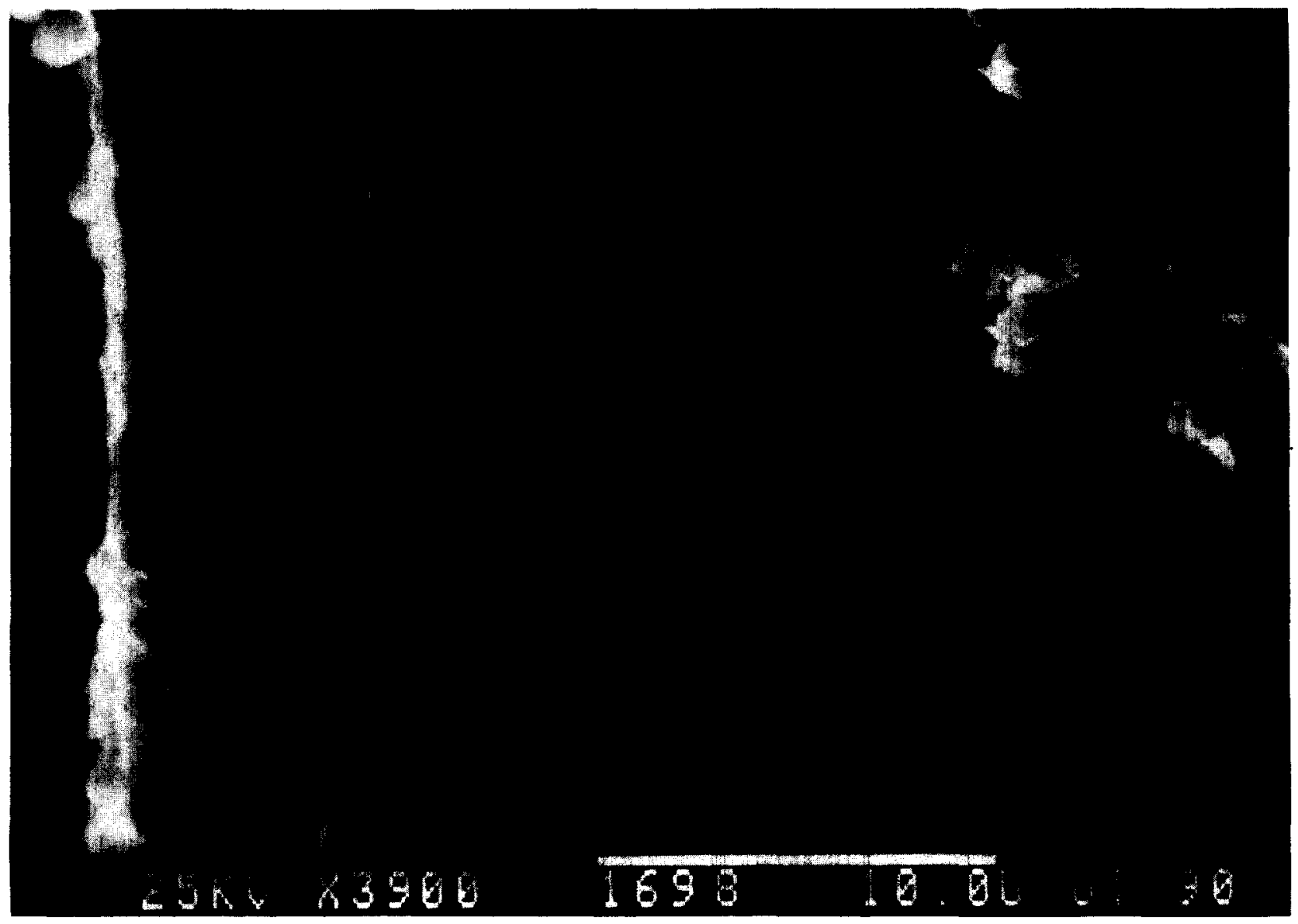

Fig. 5. SEM photograph of a cross-section of the EVD sample number 90-23. The 15SLM layer (right) is $35 \mu \mathrm{m}$ thick, the EVD YSZ layer (left) $8 \mu \mathrm{m}$.

(a)

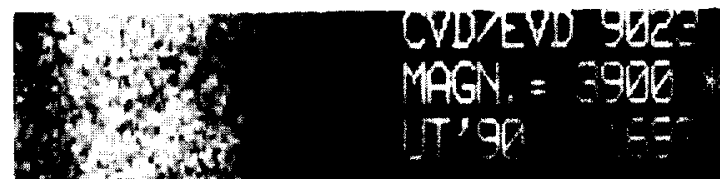

(c)
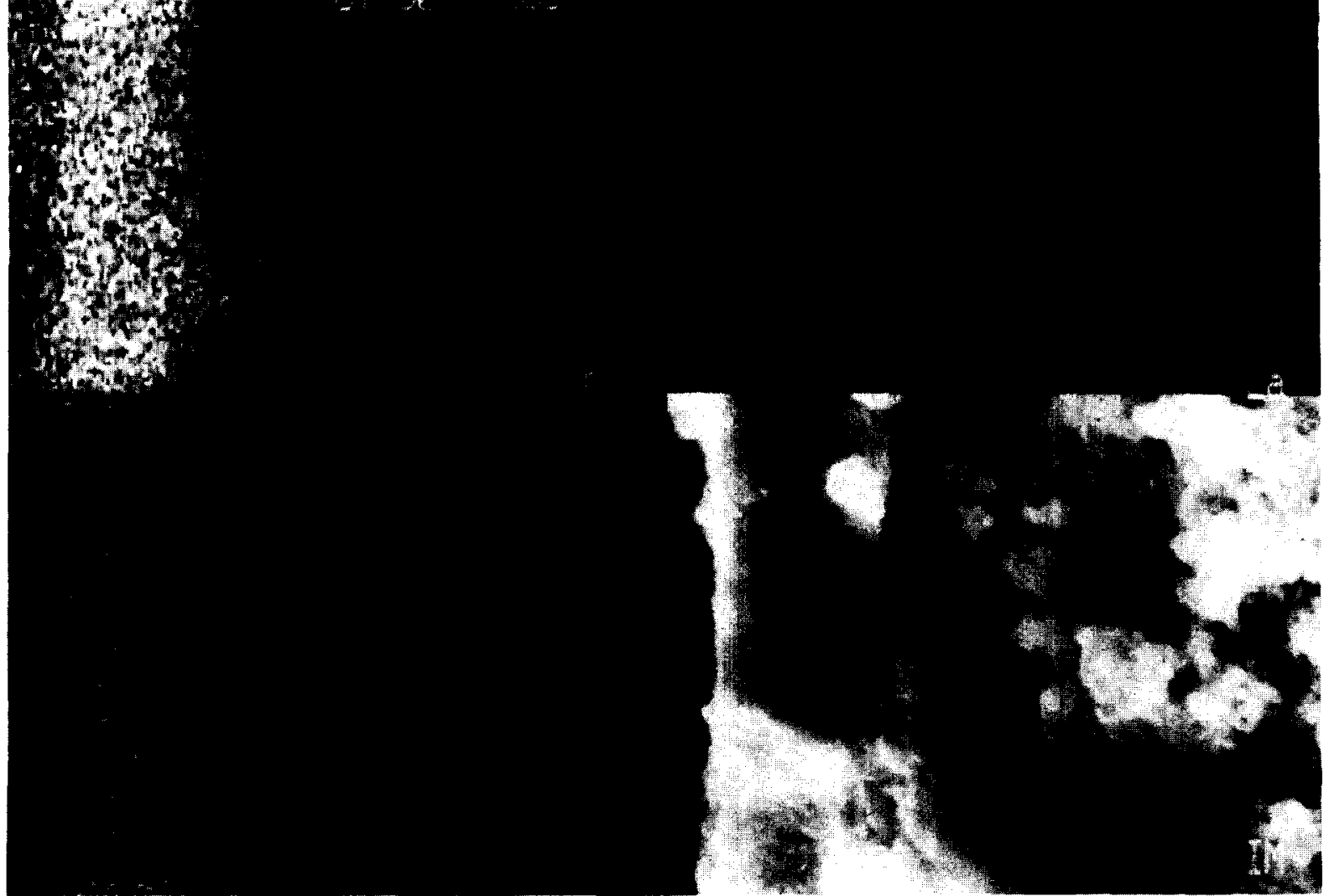

(d)

Fig. 6. Elemental mapping analysis of the cross-section of EVD sample number 90-23. (a) $\mathrm{Zr}$, (b) La, (c) Y, (d) image from Fig. 5 . 
penetrates only into the pores of the 15SLM layer. No deposit could be observed in the $\alpha$-alumina.

Similarly to the two cases shown above, all other runs performed under standard experimental conditions resulted in a YSZ deposit in the pores on the edge of the substrate that was exposed to the chloride vapour during deposition. The penetration depth varied between 5 and $20 \mu \mathrm{m}$. Depending on the total deposition time, an EVD YSZ layer was observed on the surface of the substrate. The layer thicknesses were determined from SEM photographs and are given for the several cases in Table 3. From these values and the differences between the total deposition time and the pore closure time, the film growth rate was calculated for each case under the assumption of linear growth (see Table 3; in Section 4.2 it will be shown that this is indeed valid for the type A substrate). It can be seen that for all cases with a type A substrate, the calculated values for the film growth rate are within the range $1.2-1.5 \mu \mathrm{m} \mathrm{h}^{-1}$. Only for a type B substrate (case 5 in Table 3 ) was a much higher film growth rate $\left(16 \mu \mathrm{m} \mathrm{h}^{-1}\right)$ calculated. This shows that the film growth rate depends on the type of substrate used and is independent of the type of oxygen source reactant. This will be discussed in Section 4.2.

\subsection{XRD/EDS analysis}

Figure 7 shows the XRD pattern of the EVD YSZ film of the CVD/EVD sample number 90-15. The reflections could be perfectly indexed in the facecentred cubic system. Several small reflections belonging to the $\alpha$-alumina substrate are observed as well. The lattice parameter calculated from the XRD pattern is $a=0.5151 \mathrm{~nm}$. Using the correlations of Ingel \& Lewis, ${ }^{16}$ this corresponds to a composition $\mathrm{ZrO}_{2}-13 \mathrm{~mol} \% \mathrm{Y}_{2} \mathrm{O}_{3}$. EDS analysis of the same sample, however, showed the composition of the layer to be around $\mathrm{ZrO}_{2}-8 \mathrm{~mol} \% \quad \mathrm{Y}_{2} \mathrm{O}_{3}$. The discrepancy between these two values is most likely

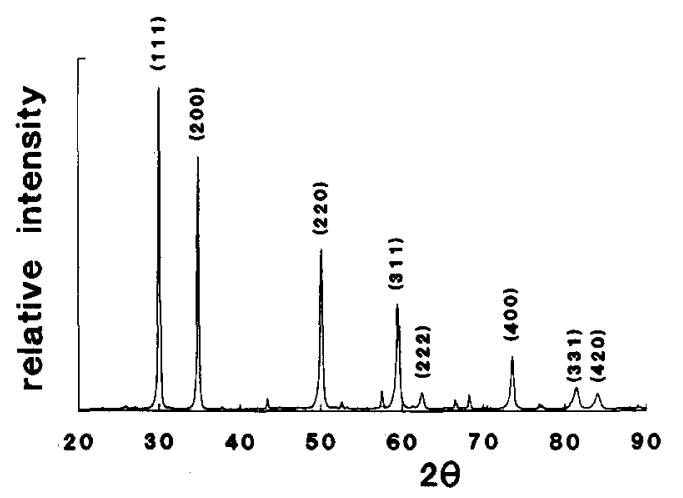

rig. 7. XRD diagram of an EVD YSZ layer (EVD sample number 90-15). The reflections are indexed for cubic phase YSZ. Non-indexed peaks are of the $\alpha$-alumina substrate. to be due to the inaccuracy of the EDS analysis in this case, because of the substantial overlap of the $Y$ and $\mathrm{Zr}$ lines, which makes a quantitative analysis of YSZ compositions unreliable.

The $\mathrm{Y} / \mathrm{Zr}$ ratio in the EVD film is controlled by the $\mathrm{Y} / \mathrm{Zr}$ ratio in the vapour phase during deposition. According to the observations made by Carolan \& Michaels, ${ }^{5}$ these films grow at the same $\mathrm{Y} / \mathrm{Zr}$ ratio as is present in the vapour phase. In the present case the $\mathrm{Y} / \mathrm{Zr}$ ratio present in the vapour phase may only be estimated from the sublimation bed temperatures and the corresponding metal chloride partial pressures. This estimated $\mathrm{Y} / \mathrm{Zr}$ ratio of $3 / 10$ in the vapour phase and the resulting film composition of around $13 \mathrm{~mol} \% \mathrm{Y}_{2} \mathrm{O}_{3}$ seem to be in line with the observations of Carolan \& Michaels. ${ }^{5}$ A method is being developed to determine experimentally the $\mathrm{Y} / \mathrm{Zr}$ ratio present in the vapour phase during deposition.

In several other cases the XRD pattern of EVD YSZ Ifilms showed the deposit to consist of a cubic and a second phase. From the phase diagram of the zirconia-yttria system, ${ }^{16.17}$ it can be seen that a decrease in yttria content results in the occurrence of a second (tetragonal or monoclinic) phase. The stability and therefore the observation of the metastable tetragonal phase depends not only on the yttria content, but also on the mean grain size. A large grain size and low yttria content in the deposited film will lead to the observation of the monoclinic phase. The observed phase composition of the YSZ deposits is thus very sensitive to the $\mathrm{Y} / \mathrm{Zr}$ ratio in the vapour phase. Ageing of the metal chlorides, especially the yttrium chloride, resulting in a lower $\mathrm{Y} / \mathrm{Zr}$ ratio, may account for the monoclinic and tetragonal phases observed sometimes in the XRD analysis. Also a less accurate location of one of the sublimation beds relative to the temperature profile in the reactor may be the reason for this observation.

As is argued in the first paragraph of this section, EDS analysis of the YSZ deposits can be used only in a qualitative way. Nevertheless EDS analysis of the YSZ deposit of the sample number 90-15 in the pores of the $\alpha$-alumina substrate (around $10-15 \mu \mathrm{m}$ from the edge) showed qualitatively a substantial increase (around three times) of the yttria content of the YSZ deposit with respect to the yttria content of the EVD layer on top of the substrate. This observation of a higher yttria content of the CVD deposit in the pores compared to that of the EVD film on top of the surface was made for all samples. This will be discussed in Section 4.1. 
Table 4. XRD data of the EVD YSZ film (sample number 9015) and YSZ powder

\begin{tabular}{cccc}
\hline 20 & $h k l$ & \multicolumn{2}{c}{$I(\%)$} \\
\cline { 3 - 4 } & & EVD film & Powder \\
\hline $30 \cdot 0$ & 111 & 100 & 100 \\
$34 \cdot 8$ & 200 & 79 & 20 \\
$50 \cdot 1$ & 220 & 50 & 52 \\
$59 \cdot 5$ & 311 & 33 & 30 \\
$62 \cdot 4$ & 222 & 6 & 6 \\
$73 \cdot 5$ & 400 & 17 & 4 \\
$81 \cdot 4$ & 331 & 7 & 8 \\
$84 \cdot 0$ & 420 & 6 & 4 \\
\hline
\end{tabular}

In the XRD pattern shown in Fig. 7 a remarkable feature is observed. Table 4 summarizes the relative peak intensities of the XRD pattern observed for the EVD YSZ layer in comparison with those observed for a polycrystalline YSZ powder sample. These figures show that the intensities of both the (200) and the (400) reflection for the EVD YSZ film are enhanced, indicating that the EVD film is oriented. This phenomenon was observed for several other samples too, and the experimental conditions under which this phenomenon occurs are being investigated. There is no indication yet whether or not, for instance, the temporary stopping of the process for the in-situ permeation measurements has an effect in this matter. Carolan \& Michaels ${ }^{5}$ reported too on a preferential growth direction during EVD of YSZ. However, these authors observed preferential growth in the [110] direction, whereas in the present case it is in the [100] direction. The reason for the discrepancy between these observations is not yet clear.

\section{Discussion}

\subsection{The CVD stage}

The mathematical modelling of the CVD stage ${ }^{12}$ showed that the distribution of the solid deposit (i.e. $\mathrm{ZrO}_{2}$ ) in the pores across the substrate and the pore narrowing rate due to this deposition are determined mainly by the following dimensionless parameters:

(1) The reaction orders for metal chloride, $N$, and for oxygen or water, $M$;

(2) the Thiele modulus, which is defined as the ratio of the reaction rate to the diffusion rate: $\Phi=K L^{2}\left(C_{\mathrm{m}}^{0}\right)^{M+N-1} /\left(D_{\mathrm{m}}^{0}\right) \cdot \bar{r}$

(3) the reactant concentration ratio: $\beta=C_{\mathrm{o}}^{0} / C_{\mathrm{m}}^{0}$;

(4) the reactant diffusivity ratio: $\lambda=D_{\mathrm{o}}^{o} / D_{\mathrm{m}}^{o}$;

(5) the vapour to solid concentration ratio: $\gamma=$ $C_{\mathrm{m}}^{0} \cdot M_{\mathrm{s}} / \rho$,

where the subscripts $m$ and o refer to the metal chloride (i.e. $\mathrm{ZrCl}_{4}$ ) and to oxygen or water, respectively, and $K$ is the reaction rate constant, $L$ the total pore length, $D^{0}$ the effective intra-pore diffusivity of the reactant, $\bar{r}$ the average initial pore radius and $C^{0}$ the reactant vapour concentration in the reactant chamber (i.e. not in the pore). $M_{\mathrm{s}}$ and $\rho$ are the molecular weight and density of the solid deposit, respectively.

Using the results of the earlier modelling analysis, ${ }^{12}$ the observation that the deposit was present only in a very small region across the substrate, near the edge that was exposed to the metal chloride vapour, was explained by a very large value of the Thiele modulus and by the conclusion that the CVD reaction between the metal chloride and water in the pores was first order with respect to the metal chloride concentration $(N=1)$ and zero order with respect to the water vapour concentration $(M=0)$. With a zero-order reaction for water, the pore closure time should be proportional to the substrate pore radius. The experimental pore closure time for the two substrates with different pore sizes was approximately the same $(0.5 \mathrm{~h})$. Also the observation that the pore closure time increased significantly when using dry air as oxygen source reactant shows that the reaction must be at least of some order with respect to the oxygen source reactant (water).

A refinement of the modelling has been performed, which accounts for these observations. ${ }^{15}$ The use of more realistic boundary conditions shows, mainly due to the fact that the diffusivity of the oxygen source reactant is larger than that of the metal chloride $(\lambda>1)$, that deposition can take place near the edge of the substrate exposed to the metal chloride vapour even with $M \neq 0$. The Thiele modulus determines the width of the deposition zone and the pore narrowing rate. The deposit being present only in a small region of not more than $20 \mu \mathrm{m}$ (i.e. only $1 \%$ of the total pore length) still shows the Thiele modulus to be very high for the type A substrates, as was concluded before. ${ }^{15}$

As suggested by the simulation results, $\mathrm{YCl}_{3}$ should penetrate deeper into the substrate pores than $\mathrm{ZrCl}_{4}$ because the value of $\lambda$ for $\mathrm{H}_{2} \mathrm{O} / \mathrm{YCl}_{3}$ is smaller than that for $\mathrm{H}_{2} \mathrm{O} / \mathrm{ZrCl}_{4}$ (i.e. the diffusivity of $\mathrm{YCl}_{3}$ is larger than that of $\mathrm{ZrCl}_{4}$ ). This would explain the EDS observations made in the present study, where an increased yttria content was found in the deposit in the pores, with respect to the yttria content of the EVD layers. Carolan \& Michaels ${ }^{3}$ also considered the $\mathrm{Y} / \mathrm{Zr}$ ratio in the deposit in their modelling. Assuming that the relative reaction rates of $\mathrm{YCl}_{3}$ and $\mathrm{ZrCl}_{4}$ with water are equal, these authors came to the similar prediction that the deposited oxide would become enriched in yttria 
deeper in the pore, due to the higher diffusivity of $\mathrm{YCl}_{3}{ }^{3}$

From the pressure dependence of the permeability of a homogeneous medium with micro and/or meso pores, wherein Knudsen diffusion and laminar flow occur as gas transport mechanisms, an estimate for the average pore radius can be obtained. ${ }^{18}$ The SEM observations of the YSZ deposits during CVD showed that these deposits occur only in a small region $(5-20 \mu \mathrm{m})$ on the edge of the substrate exposed to the metal chloride vapour during deposition. In a first approximation, the system formed after 15 min deposition (see Section 3.1) can be regarded as a two-layer system consisting of the part of the $\alpha$-alumina substrate without a deposit and the part of the $\alpha$-alumina (about $20 \mu \mathrm{m}$ thick) with YSZ deposits in the pores, referred to as top layer here. Since permeability is defined as a reciprocal resistance against mass transport, a multilayer system can be considered as a set of resistances in series. ${ }^{18}$ Following the procedures of Uhlhorn et $a l .{ }^{18}$ for well-defined ceramic membranes, the permeability of the $20 \mu \mathrm{m}$ thick top layer of $\alpha$ alumina with YSZ deposit was calculated from the permeabilities measured before deposition and after $15 \mathrm{~min}$ deposition. From the thus-obtained pressure dependence of the permeability of the top layer, an average pore radius for this top layer was estimated. Up to now, however, these calculations have not resulted in the unambiguous proof of pore narrowing, i.e. the estimated average pore radius in the top layer ( $\alpha$-alumina with YSZ deposit) was never substantially smaller than the average pore radius of the model type A substrate.

\subsection{The EVD stage}

In several studies ${ }^{4,19,20}$ the kinetics of the EVD stage have been modelled. In these studies, the electrochemical transport through the growing EVD film has been assumed to be the rate-limiting step. In this situation the function of the EVD film thickness versus deposition time, $H(t)$, is parabolic. This parabolic behaviour was observed experimentally by Carolan $\&$ Michaels ${ }^{4}$ and Pal \& Singhal. ${ }^{19}$

Instead of calculating the film growth rate for every case separately (see Table 3), in Fig. 8 the EVD film thickness is given as a function of the total effective deposition time. The data points in Fig. 8 are for several cases using a type $A$ substrate and with a $\mathrm{H}_{2} / \mathrm{H}_{2} \mathrm{O}$ mixture or an air $/ \mathrm{H}_{2} \mathrm{O}$ mixture as oxygen source reactant. It has already been noted (see Section 3.2) that the film growth rate is independent of the type of oxygen source reactant. A linear relation is observed up to deposition times of

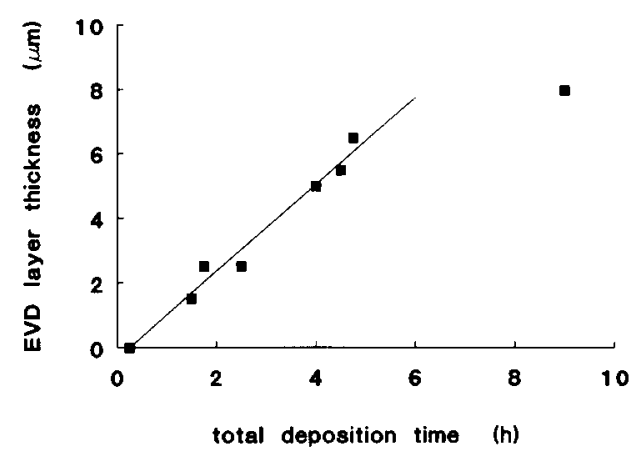

Fig. 8. Layer thickness of EVD YSZ layers on type A substrates at standard conditions as function of the total effective deposition time.

$5 \mathrm{~h}$. The slope of the line gives a film growth rate of $1.4 \mu \mathrm{m} \mathrm{h}^{-1}$. The intercept with the time axis (at $0.4 \mathrm{~h}$ ) indicates the pore closure time, which is close to the experimentally observed value. The linear relation observed indicates that the electrochemical transport in the growing film is not rate limiting in the presented EVD experiments. Oxygen permeation measurements performed in this laboratory on EVD YSZ films ${ }^{21}$ also indicate that bulk electrochemical transport is not the rate-limiting step in the EVD process performed.

In the modelling study performed, all major mass transport steps involved in the EVD process were considered: ${ }^{13}$

(1) Oxygen/water diffusion through the pores of the substrate to the growing film interface;

(2) reduction reaction at the water/film interface;

(3) bulk electrochemical transport in the film, and

(4) oxidation reaction at the metal chloride/film interface.

The experimental value found for the film growth rate of $1.4 \mu \mathrm{m} \mathrm{h}^{-1}$ is close to the maximum film growth rate of $1.6-1.7 \mu \mathrm{m} \mathrm{h}^{-1}$ calculated assuming the oxygen/water diffusion through the substrate pores to be the rate-limiting step. ${ }^{13}$ The maximum film growth rate calculated assuming the water/ oxygen reduction reaction to be rate limiting is much lower, but the accuracy of this calculation has to be doubted..$^{13}$ The assumption of this step being rate limiting cannot account for the differences in film growth rate observed here between the type $A$ and type B substrates (see Table 3). This difference can only be explained by the pore diffusion being rate limiting. Moreover, the change of the oxygen source reactant from a $\mathrm{H}_{2} / \mathrm{H}_{2} \mathrm{O}$ mixture to an air $/ \mathrm{H}_{2} \mathrm{O}$ mixture did not result in an increased film growth rate, which would be expected if the reduction reaction at the water/film interface were rate 
limiting. ${ }^{13}$ In conclusion, the experimental results agree well with the model for the EVD growth kinetics with the pore diffusion as rate-limiting step in supports of type A.

The difference between the linear relation observed in the present study and the parabolic behaviour observed by Carolan $\&$ Michaels ${ }^{4}$ and $\mathrm{Pal} \&$ Singhal ${ }^{19}$ is thought to be caused primarily by the different substrates used. The difference in average pore radius of the substrates results in different relative resistances for each oxygen transport step in the EVD process between the present study and the other reported studies. Preliminary calculations on a refined model ${ }^{22}$ indicate that in the present EVD experiments (type A substrate, pore diameter of $0.2 \mu \mathrm{m}$ ) after a certain deposition time the rate-limiting step might change to bulk electrochemical transport. At this time the film has reached such a thickness that the resistance for oxygen transport in the film has become of the same order as the resistance in the substrate pores. This time strongly depends on the substrate pore dimension, but also on other experimental conditions, such as the oxygen partial pressure difference between the chloride chamber and the water chamber, and may range from several seconds up to $24 \mathrm{~h}$ or even more. The deviation from linearity observed in Fig. 8 for deposition times of 5 h or more (although only one more point is indicated) points to a change in the rate-limiting step at a time of around $5 \mathrm{~h}$ in the EVD experiments with type A substrates. In the case of the experiments of Carolan \& Michaels (substrate pore diameter of $2 \mu \mathrm{m})^{4}$ and $\mathrm{Pal}$ $\&$ Singhal (substrate pore diameter $>10 \mu \mathrm{m}$ ), ${ }^{19}$ this change might already occur at growing times of several minutes. The time period with a linear behaviour is then probably too short to be even observed. Also, in the case of the type B substrates (pore diameter of $10 \mu \mathrm{m}$ ), the refined model predicts a parabolic behaviour of the EVD film thickness as a function of the EVD time for deposition times larger than several minutes. The value reported for the growth rate of the type B substrate (Table 3; case 5) is thus merely an average value. The observation of this larger film growth rate for the type B substrates than that for the type A substrates is thus due to the fact that the pore diffusion is no longer the ratelimiting step in the type B substrates after several minutes of deposition. Experiments are being performed with the type B substrates to verify this prediction. More theoretical and experimental studies are needed to understand how the EVD experimental conditions affect the resistance for oxygen transport in each step of the EVD process.

\section{Conclusions}

The modified chemical vapour deposition of yttriastabilized zirconia (YSZ) on porous substrates results in YSZ deposition in the substrate pores in a small region $(\leq 20 \mu \mathrm{m})$ at the edge of the substrate exposed to the metal chloride vapour during deposition. The yttria-zirconia deposit in the pores is enriched in yttria with respect to the yttrium to zirconium ratio present in the vapour phase, due to a higher diffusivity of the yttrium chloride. Films grown on the surface of the substrate in the electrochemical vapour deposition stage seem to have the same yttrium to zirconium ratio as is present in the vapour phase. The film growth kinetics are, under the present experimental conditions, controlled by the pore diffusion of the oxygen source reactant.

\section{Acknowledgements}

The investigations were partly supported by the Dutch Ministry of Economic Affairs (Research Project 'ECVD Synthesis and Properties of Porous Composite Systems', IOP Technical Ceramics No. $87 \mathrm{~A} 045)$ and partly performed under contract with the Commission of the European Communities (CEC) within the Non-Nuclear Energy $R$ and D Programme (Research Contract 'Membrane Based Thin Layer SOFC Technology', No. EN3E-0175NL). Mr P. Fransen, Mr D. Wesseling and Mr R. Kuipers are acknowledged for constructing the CVD/EVD apparatus and running the experiments.

\section{References}

1. Isenberg, A. O., Growth of refractory oxide layers by electrochemical vapor deposition (EVD) at elevated temperatures. In Proc. Symp. Electrode Materials, Processes for Energy Conversion and Storage, eds J. D. E. McIntyre, S. Srinivasan \& F. G. Will. The Electrochem. Soc. Inc., Princeton, NJ, 77-6 (1977) 572-83.

2. Dietrich, G. \& Schäfer, W., Advances in the development of thin-film cells for high temperature electrolysis. Int. J. Hydrogen Energy, 9 (1984) 747-52.

3. Carolan, M. F. \& Michaels, J. N., Chemical vapour deposition of yttria-stabilized zirconia on porous supports. Solid State Ionics, 25 (1987) 207-16.

4. Carolan, M. F. \& Michaels, J. N., Growth rates and mechanism of electrochemical vapour deposited yttriastabilized zirconia films. Solid State Ionics, 37 (1990) 189-95.

5. Carolan, M. F. \& Michaels, J. N., Morphology of electrochemical vapour deposited yttria-stabilized zirconia films. Solid State Ionics, 37 (1990) 197-202.

6. Lin, Y. S., de Haart, L. G. J., de Vries, K. J. \& Burggraaf, A. J., Modification of ceramic membranes by CVD and EVD for gas separation, catalysis and SOFC application. In 
Euro-Ceramics, Vol. 3, ed. G. de With, R. A. Terpstra \& R. Metselaar. Elsevier Science Publishers, London, 1989, pp. $3590-5$.

7. Burggraaf, A. J. \& Keizer, K., Synthesis of inorganic membranes. In Inorganic Membranes: Synthesis, Characterization and Properties, ed. R. Bhave. Van Nostrand Reinhold, New York, 1990, in press.

8. Hsieh, H. P., Inorganic membranes. AIChE Symp. Ser., 84(261) (1988) 1-18.

9. Keizer, K. \& Burggraaf, A. J., Porous ceramic materials in membrane applications. Science of Ceramics, 14 (1988) 83-94.

10. Uhlhorn, R. J. R., Huis in't Veld, M. H. B. J., Keizer, K. \& Burggraaf, A. J., High permselectivities of microporous silica-modified $\gamma$-alumina membranes. J. Mater. Sci. Lett., 8 (1989) 1135-8.

11. De Haart, L. G. J., Lin, Y. S., de Vries, K. J. \& Burggraaf, A J., Dünnschichtverfahren zur herstellung von oxidkeramischen Brennstoffzellen-Ein modifizierter CVD/ EVD-prozess. In Brennstoffzellen, ed. H. Wendt \& V. Plzak. VDI Verlag, Düsseldorf, 1990, pp. 144-52.

12. Lin, Y. S., de Vries, K. J. \& Burggraaf, A. J., CVD modification of ceramic membranes: simulation and preliminary results. J. de Phys., Colloque C5, 50 (1989) 861-72.

13. Lin, Y. S., de Haart, L. G. J., de Vries, K. J. \& Burggraaf, A. J., A kinetic study on the electrochemical vapour deposition of solid oxide electrolyte films on porous substrates. $J$. Electrochem. Soc., 137 (1990) 3960-6.

14. Huijsmans, J. P. P., van der Molen, S. B. \& Siewers, E. J., Membrane-based thin layer SOFC components. In EuroCeramics, Vol. 3, ed. G. de With, R. A. Terpstra \& R. Metselaar. Elsevier Science Publishers, London, 1989, pp. $3.626-30$.
15. Lin, Y. S., Fransen, P., de Vries, K. J. \& Burggraaf, A. J., Experimental study on CVD modification of ceramic membranes. In Proceedings of the 11th International Conference on CVD, Proc. Vol. 90-12, ed. K. E. Spear \& G. W. Cullen. The Electrochemical Society Inc., Pennington, NJ, 1990, pp. 539-45.

16. Ingel, R. P. \& Lewis, III, D., Lattice parameters and density for $\mathrm{Y}_{2} \mathrm{O}_{3}$-stabilized $\mathrm{ZrO}_{2}$. J. Am. Ceram. Soc., 69 (1986) 325-32.

17. Scott, H. G., Phase relationships in the zirconia-yttria system. J. Mater. Sci., 10 (1975) 1527-35.

18. Uhlhorn, R. J. R., Huis in 't Veld, M. H. B. J., Keizer, K. \& Burggraaf, A. J., New ceramic membrane materials for use in gas separation applications. Science of Ceramics, 14 (1988) 551-6

19. Pal, U. B. \& Singhal, S. C., Electrochemical vapor deposition of yttria-stabilized zirconia films. In Proceedings of the Ist International Symposium on Solid Oxide Fuel Cells, Proc. Vol. 89-11, ed. S. C. Singhal. The Electrochemical Society Inc., Pennington, NJ, 1989, pp. 41-53.

20. Dekker, J. P., Kiwiet, N. J. \& Schoonman, J., Electrochemical vapor deposition of SOFC components. In Proceedings of the 1st International Symposium on Solid Oxide Fuel Cells, Proc. Vol. 89-11, ed. S. C. Singhal. The Electrochemical Society Inc., Pennington, NJ, 1989, pp. 57-66.

21. Lin, Y. S., de Vries, K. J. \& Burggraaf, A. J., Oxygen semipermeable dense membrane composite prepared by electrochemical vapor deposition. In Proceedings of the 1990 International Congress on Membranes and Membrane Processes, Vol. I, 20-24 August 1990, Chicago, pp. 552-4.

22. De Haart, L. G. J., Lin, Y. S., de Vries, K. J. \& Burggraaf, A. J. kinetic study of electrochemical vapour deposition. Solid State Ionics, (in press). 